\title{
Effect of Amazonian tree species on soil and pasture quality in silvopastoral systems
}

\author{
Alexandre de Azevedo OLIVAL ${ }^{1 *} \mathbb{C}$, Saulo Eduardo Xavier Franco de SOUZA², \\ Jozivaldo Prudêncio Gomes de MORAES ${ }^{3}$, Mariana CAMPANA ${ }^{3}$ \\ 1 Universidade do Estado de Mato Grosso, Av. Perimetral Rogério Silva, s/n, CEP 78580-000, Alta Floresta, MT, Brazil \\ ${ }^{2}$ Instituto Ouro Verde, Rua Ipê Lilás 101, CEP 78580-000, Alta Floresta, MT, Brazil \\ ${ }^{3}$ Universidade Federal de São Carlos, SP-330, km 174, Zona Rural, CEP 13604-900, Araras - SP, Brazil \\ Corresponding author: aolival@unemat.br; (D) https://orcid.org/0000-0001-5080-3846
}

\begin{abstract}
With the expansion of livestock in the Amazon region, a high percentage of pasture areas are degraded and unproductive. Novel strategies are needed, including the use of native tree species, to simultaneously achieve economic and ecosystem benefits. This study aimed at assessing the effects of five multipurpose native tree species on soil fertility and forage quality of Urochloa brizantha pastures in the southern Amazon. Soil and forage samples were collected under the crown and adjacent to 25 isolated trees belonging to five species during a dry and a rainy season. The presence of native trees positively affected the level of potassium, calcium and manganese in the soil, as well as the mineral matter and crude protein of the forage, especially in the dry season, suggesting a protective effect against the seasonal drought. The tree species had variable effects on soil fertility and forage quality. Soil under Apeiba tibourbou had higher potassium levels, while the forage under Handroanthus serratifolius had higher protein and fiber content. Our results indicate that it is important to diversify silvopastoral systems in the Amazon through the use of native tree species, contributing to the design of novel silvopastoral strategies in the region. Common multipurpose tree species with widespread natural distribution could be used as a complementary aspect of pasture management to provide a protective effect against drought, contribute to enhanced nutrient cycling and even increase forage quality.
\end{abstract}

KEYWORDS: agroecosystems, soil conservation, animal nutrition, sustainable livestock, multipurpose native trees

\section{Efeitos de espécies arbóreas amazônicas sobre o solo e qualidade da forragem em sistemas silvipastoris}

\section{RESUMO}

Com a expansão da pecuária na região amazônica, um alto percentual de pastagem está degradada e improdutiva. São necessárias novas estratégias, incluindo o uso de espécies de árvores nativas, para obter simultaneamente benefícios econômicos e ecossistêmicos. Este estudo objetivou avaliar os efeitos de cinco espécies arbóreas nativas multifuncionais na fertilidade do solo e qualidade da forragem em pastagens de Urochloa brizantha na Amazônia Meridional. Para isso, amostras de solo e forragem foram coletadas sob a copa e áreas adjacentes de 25 árvores isoladas pertencentes a cinco espécies durante uma estação seca e uma chuvosa. A presença de árvores nativas afetou positivamente o nível de potássio, calcio e magnésio no solo, bem como aumentou a matéria mineral e proteína bruta da forragem, especialmente na estação seca, sugerindo um efeito protetivo contra a seca sazonal. As espécies arbóreas tiveram efeitos variáveis sobre a fertilidade do solo e qualidade da forragem. O solo sob Apeiba tibourbou apresentou aumento nos teores de potássio, enquanto a forragem sob Handroanthus serratifolius apresentou melhor qualidade no que se refere a proteínas e fibras. Nosso estudo indica a importância da diversificação dos sistemas silvipastoris na Amazônia por meio do uso de espécies arbóreas nativas, contribuindo para o desenho de estratégias silvipastoris inovadoras na região. Espécies arbóreas multifuncionais comuns de ampla distribuição natural podem ser utilizadas como um aspecto complementar do manejo de pastagens para fornecer um efeito protetivo contra a seca, aprimorar a ciclagem de nutrientes e aumentar a qualidade da forragem.

PALAVRAS-CHAVE: agroecossistemas, conservação do solo, nutrição animal, pecuária sustentável, espécies nativas multifuncionais

CITE AS: Olival, A.d.A.; Souza, S.E.X.F.d.; Moraes, J.P.G.d.; Campana, M. 2021. Effect of Amazonian tree species on soil and pasture quality in silvopastoral systems. Acta Amazonica 51: 281-290. 


\section{INTRODUCTION}

Agriculture-dominated landscapes cover approximately 50\% of tropical biomes, with pastures being an ultimate cause of two thirds of deforested land in the neotropics (Lerner 2015). In Latin America, there is a strong link between deforestation and livestock expansion, either for establishing pastures or for producing grains for animal feed (FAO 2012). Livestock expansion throughout forested regions has brought short-term benefits, considering the sheer financial volume involved with this activity. However, livestock farming has disadvantages in the long term, especially associated with biodiversity loss, carbon emissions, and reduction or disruption of ecosystem services such as species habitat, conservation of soil and water resources, and carbon stock and sequestration (Barret et al. 2013). Since worldwide food demand is increasing and food production is directly linked with biodiversity and ecosystem services, it is of paramount importance to develop and consolidate novel agricultural systems that could increase productivity while mitigating climate change (IPCC 2019).

Silvopastoral systems are one of the possible solutions towards a more efficient production system, consisting of an intentional combination of various trees and livestock using different arrangements through time and space (Almeida $e t$ al. 2013). These systems produce extensive benefits that vary according to local traits and designs, generally including the establishment of biological corridors (Harvey et al. 2005; Vergne et al. 2016), and improvements to the biological, chemical and physical structure of the soil (Nair 2007; Pinho et al. 2012; Martinez et al. 2014; ), forage quality (Bernardi et al. 2016), and thermal comfort of animals (West 2003; Carvalho et al. 2018).

Several studies on the effects of the presence of native trees in pastures, especially in the tropics, demonstrated benefits such as increased animal productivity, improved quality of forage plants and improved physical, chemical and biological parameters of the soil (Franke 1999; Delgado et al. 2014; Muroe and Isaac 2014; Santos et al. 2016; Camero-Rey and Diaz 2017; Ledesma et al. 2017; England et al. 2020; Alvarez et al. 2021). There is solid evidence that different tree species affect soil fertility in temperate environments by minimizing erosion and leaching while increasing nutrient inputs, as well as enhancing soil structure and biological activity (Binkley and Giarina 1998; Schroth and Sinclair 2003; Devendra 2014; Chará et al. 2019; Sarvade et al. 2019; Rozek et al. 2020).

These effects are related to the optimization of nutrient cycling and the establishment of a microenvironment that improves forage quality (Schroth and Sinclair 2003; Lambers et al. 2008; Sileshi et al. 2014; Bernardi et al. 2016; Araujo et al. 2020). In Brazil, the most widely recommended systems are based on the incorporation of exotic tree species such as eucalyptus (Eucalyptus spp.) and teak (Tectona grandis L.f.), mainly to increase financial profitability land use. However, in northern Mato Grosso state (Brazil), scattered native trees in pastures are used to provide shade and nutritional supplement (from fruits and leaves) for the herd, especially in the dry season (pers. obs. by the authors). These are usually the main reasons for farmers to keep trees in pastures (Harvey and Haber 1999; Lasco et al. 2016; Oliveira and Carvalhaes 2016; Olival et al. 2020).

As the action mechanisms of native Amazonan tree species on pastures are still little known, we assessed the forage quality and soil fertility in pasture under the influence of five native tree species during the rainy and dry season in southern Amazonia. Our hypothesis was that the presence of native trees on pastures positively influences soil fertility as well as forage quality and that these effects depend on the characteristics of the tree species and also on the pasture management.

\section{MATERIAL AND METHODS}

\section{Study area}

The study was carried out in two farms in the municipality

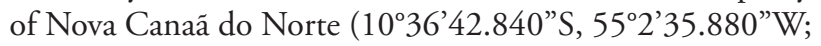
$10^{\circ} 48^{\prime} 59.654^{\prime \prime}$, $\left.55^{\circ} 41^{\prime} 54.350^{\prime \prime} \mathrm{W}\right)$ and two farms in Nova

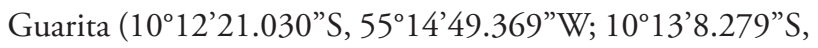
$\left.55^{\circ} 23^{\prime} 18.122^{\prime \prime} \mathrm{W}\right)$, in northern Mato Grosso state, Brazil, all within the watershed of the Teles Pires River, a major tributary of the Tapajós River in the Amazon basin. Local landscapes are characterized by large expanses of pasture interspersed with soy and cotton crops and native vegetation, mainly represented by open tropical forest fragments (IBGE 2012). Soil is dystrophic red-yellow podzolic (Mato Grosso 2000). The climate is tropical monsoon (type Am by the Köppen system), with total annual precipitation around $3000 \mathrm{~mm}$, mainly from November to March, and average annual temperature above $26^{\circ} \mathrm{C}$ (Alvarez et al. 2013).

The areas are located in the "arc of deforestation" of the Amazon region, where large areas of forest have been transformed into pastures over the last 30 years. In many pastures, remnant trees persist or are allowed to grow, especially in family farms, which account for more than $80 \%$ of rural properties in northern Mato Grosso (IBGE 2019). The four rural properties sampled in the study participate in forest-restoration and agroforestry projects since 2010 in partnership with local organizations.

\section{Species selection}

For the selection of trees to test the effect on soil fertility and nutritional properties of the forage, we mapped all trees scattered across 237.9 ha in pastures of 39 family farms across the study area. Based on this survey, three workshops were held with the farm owners to decide, based on their perception, which of the naturally occurring tree species on their lands had the highest potential to bring benefits for their productive systems. The main benefits identified by the farmers were the 
provision of thermal comfort to livestock through shade and the improvement of soil conditions.

We selected five tree species considered by the farmers as having the highest potential to bring benefits: Apeiba tibourbou Aubl. (Malvaceae), Handroanthus serratifolius (Vahl.) S. Grose (Bignoniaceae), Maclura tinctoria (L.) D.Don ex Steud (Moraceae), Platymiscium floribundum Vogel (Fabaceae) and Samanea tubulosa (Benth.) Barneby \& J.W.Grimes (Fabaceae). These are multipurpose species with a widespread natural occurrence in Brazil and adjacent countries, with spontaneous colonization and persistence in local pastures. All provide high quality timber, $H$. serratifolius being currently the most valued Brazilian timber species (Brancalion et al. 2018). Platymiscium floribundum and S. tubulosa are N-fixing species (de Souza 2010). Leaves of $A$. tibourbou and $M$. tinctoria, and fruits of S. tubulosa provide alternative forage for cattle, as indicated by the farmers and by Carvalho (2007). See Supplementary Material (Table S1) for further information on functional and silvicultural characteristics of the species.

\section{Sampling design}

For each selected tree species, we identified one pasture containing five isolated individuals in the same paddock. Trees had to be mature, older than 10 years and isolated from other trees by at least $50 \mathrm{~m}$, in order to avoid confusing the effects of focal trees with those of neighboring trees. Out of the 39 mapped farms, only four met all these criteria. Three contained sets of one species each, and one contained sets of two species (H. serratifolius and S. tubulosa). The pastures in all four farms were of palisade grass (Urochloa brizantha (A. Rich) R.D.Webster), the most common forage grass used in the southern Amazon.

Pastures containing H. serratifolius and S. tubulosa covered 3.41 ha and had $4.7 \%$ of total tree cover, including trees of other species, and the highest cattle-stocking rate (6.3 AU $\mathrm{ha}^{-1}$ ), with 14 paddocks for rotational grazing and grassfed supplementation during the dry season. The pasture containing $A$. tibourbou covered 5.29 ha with $13.1 \%$ tree cover. This was the only pasture where cattle received no feed supplementation in the dry season, and had the lowest cattle-stocking rate $\left(0.6 \mathrm{AU} \mathrm{ha}^{-1}\right)$ and grazing divided in 11 paddocks. The pasture containing $M$. tinctoria covered 8.17 ha with $9.8 \%$ tree cover, a cattle-stocking rate of $1.32 \mathrm{AU}^{\text {ha- }}$ 1,23 paddocks and grass supplementation in the dry season. The pasture containing P. floribundum covered 1.93 ha, with the highest proportion of tree cover (31.6\%), cattle-stocking rate of $0.97 \mathrm{AU} \mathrm{ha}^{-1}$, and five paddocks. Resting time of the pastures varied around 30 days, except for the A. tibourbou pasture, which rested for 45 days in the rainy season, and 120 days in the dry season.

For each tree, we measured diameter at breast height $(\mathrm{DBH})$ and crown area by measuring eight crown-radius lengths (distance from trunk to crown projection limits using measuring tapes) in order to form eight triangles. The crown area was then calculated from the sum of the triangle areas (Gomes et al. 2003) (Supplementary Material, Table S2). We collected forage and soil samples in the crown area of each tree (considered to be directly influenced by the tree presence) and in areas $5 \mathrm{~m}$ outside the crown area, considered not to be influenced by the trees, asthe benefits of trees on soil decrease with increasing distance from the tree (Oliveira et al. 2012). Thus, although there were other trees in the pastures, each focal tree was assumed to be isolated from the effect of other trees of the same or other species. Forage and soil samples were collected during one dry (August 2017) and one rainy season (January 2018). In each season, we randomly collected four forage and five soil samples within the crown area of each focal tree, and four and five samples, respectively, outside the crown area. For each forage sample, we placed a hollow square (1 $\mathrm{m}^{2}$ ) and collected the forage mass (cut at $2 / 3$ of blade height) inside the square area. The soil samples were collected at 0-10 $\mathrm{cm}$ depth. The samples for each tree and season were pooled to form one composite sample of forage and one of soil under the canopy (within the crown area), and one sample each off the canopy (outside the crown area). Therefore, we had five replicates per species and season for each treatment (presence or absence of the tree).

The fresh mass of the forage samples was weighed in the field and then transported to the laboratory, where they were oven dried at $65^{\circ} \mathrm{C}$ for $72 \mathrm{~h}$ to obtain the dry mass. The percentage of mineral materials (MM), ethereal extract (EE) and crude protein $(\mathrm{CP})$ were quantified according to AOAC (2012). Neutral detergent fiber (NDF), acid detergent fiber (ADF) and lignin content (LC) were determined following Van Soest et al. (1991). The soil samples were analyzed for organic matter $(\mathrm{OM})$, calcium $(\mathrm{Ca})$, magnesium $(\mathrm{Mg})$, potassium (K), phosphorus (P) following Embrapa (2009). Forage samples were analyzed at the Laboratory of Animal Nutrition of Universidade Federal de São Carlos, and soil samples were analyzed at the Laboratory of Soil and Leaf Analysis of Universidade so Estado de Mato Grosso.

All farms showed some sign of pasture degradation, mainly due to management problems. We found a high incidence of invasive plants and sudden-death syndrome, as well as signs of poor quality of forage plants, especially in the dry season. Forage yield was not the focus of this study, but, for the sake of charcterization, we observed that average forage availability varied from around $300 \mathrm{~kg}$ dry mass ha- ${ }^{-1}$ off the canopy of M. tinctoria in the dry season to almost $5,000 \mathrm{~kg} \mathrm{ha}^{-1}$ off the canopy of H. serratifolius in the rainy season. There was a two to three-fold reduction in pasture dry mass in the dry season, when yield varied from 300 to almost $2,000 \mathrm{~kg} \mathrm{ha}^{-1}$. In the rainy season it varied from 2,000 to almost $5,000 \mathrm{~kg} \mathrm{ha}^{-1}$. Average yield difference between forage grown under and off canopy varied from less than $20 \mathrm{~kg}$ in the dry season $A$. tibourbou pasture to almost $1,000 \mathrm{~kg} \mathrm{ha}^{-1}$ in the $M$. tinctoria pasture. 


\section{Data analysis}

As forage quality proxies, we used the proportion of MM, CP, NDF, ADF and LC, and as proxies for soil fertility we used $\mathrm{P}, \mathrm{K}, \mathrm{Ca}, \mathrm{Mg}$ and $\mathrm{OM}$. The adherence of the variables to different theoretical distribution functions was tested through skewness and kustosis comparisons using graphical analysis of the package 'fitdistrplus' (Delignette-Muller and Dutang 2015), in the R environment ( $R$ Core Team 2019). Then we used the information-theoretic approach for model selection (Burnhan and Anderson 2002) by fitting generalized linear mixed models (GLMM) to the data of each of the above dependent variables and using tree presence/absence, season and species as categorical fixed effects. To account for repeated measures of individual trees, we fitted random intercept models, with varying intercept among individuals. The beta distribution family with a logit link was used to fit forage quality models, while the gamma family with a $\log$ link was used to fit soil fertility models. The models were fitted with the aid of 'glmmTMB' and 'lme4' packages (Bates et al. 2015;
Brooks et al. 2017). Summary statistics such as the coefficient of determination $\left(R^{2}\right)$ and intra-class correlation coefficients (ICC) were computed according to Nakagawa et al. (2017). Finally, Wald Type II chi-square tests on the fixed effects and Tukey post hoc tests were performed for every selected model (Fox and Weisberg 2019). Confidence intervals for model estimates were derived from Wald approximation.

\section{RESULTS}

The best-fitting GLMM models for soil fertility included a significant effect of tree presence for all variables (except $\mathrm{P})$ as well as variation between seasons and among species (Supplementary Material, Table S3). There was a general tendency of decrease in soil fertility in the dry season (Figure 1). The selected models explained between $65 \%(\mathrm{P})$ and $90 \%$ (K) of the observed variance in soil fertility, as indicated by the conditional coefficient of determination $\left(\mathrm{R}_{\text {GLMM }(c)}^{2}\right)$ (Table 1). The presence of trees accounted for 10 to $28 \%$ of observed variation, as indicated by the adjusted ICC values (Table 1).
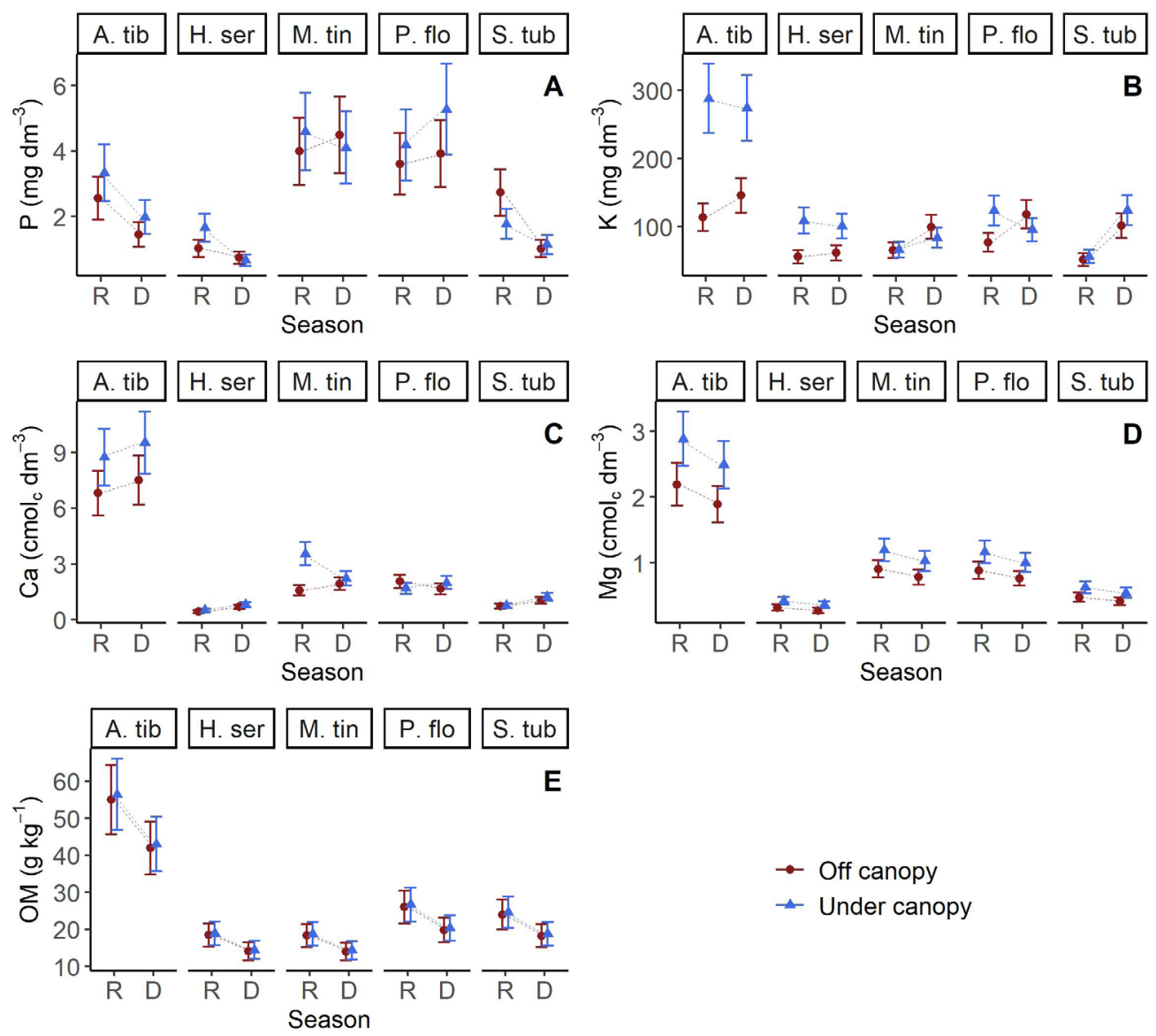

$\rightarrow$ Off canopy

- Under canopy

Figure 1. Estimated marginal means and standard errors of models selected to explain the variance in parameters of soil inside and outside the crown area of isolated trees of five native species in four pastures in the dry and rainy season in northwestern Mato Grosso State, Brazil. A - phosphorus (P); B - potassium (K); C - calcium (Ca); D - magnesium (Mg); E- organic matter (OM). A. tib = Apeiba tibourbou; H. ser = Handroanthus serratifolius; M. tin = Maclura tinctoria; P. flo = Platymiscium floribundum; $\mathrm{S}$. tub = Samanea tubulosa. Season: $\mathrm{R}=$ rainy; $\mathrm{D}=$ dry. This figure is in color in the electronic version. 
Incidence ratios of tree presence from our soil models indicated significantly higher levels of K [153\% (95\% CI: 84 $-249 \%)]$, Ca [28\% (10 - 82\%)] and $\mathrm{Mg}$ [32\% (11 - 55\%)] under canopy than off canopy, when keeping all other variables constant (Supplementary Material, Figure S1). K content was significantly higher in both seasons under $A$. tibourbou (rainy: $z$ ratio $=-5.672, p<0.001 ;$ dry: $z$ ratio $=-3.849, p=0.0001$ ) and (almost twice as high under the trees), H. serratifolius (rainy: $z$ ratio $=-4.024, p=0.0001$; dry: $z$ ratio $=-2.972, p$ $=0.0030)$, and $P$. floribundum in the rainy season $(z$ ratio $=$ $-2.892, p=0.0038$ ) (Figure 1b).

The best-fitting models for forage quality (except for LC) included the interaction effects of tree presence, season and species (Table 1; Supplementary Material, Table S4). Contrary to the soil fertily models, there was no significant influence of random effects of individual trees on forage-quality attributes (Supplementary Material, Figure S1b and S2b). The best-fitting LC model included seasonality and species (a proxy for sampling sites) (Figure 2e), but not tree presence (Supplementary Material, Table S4).

As expected, $\mathrm{MM}$ and $\mathrm{CP}$ content in the forage decreased in the dry season in all cases, while fiber content increased in most cases (Figure 2). Tree presence tended to increase MM and $\mathrm{CP}$ in forage, with positive effects of varying magnitude in all species (Figure 2). MM was significantly higher under A. tibourbou in the dry season ( $t$ ratio $=-4.787, p<0.0001)$, M. tinctoria in both seasons (dry: tratio $=-2.335, p=0.0221$; rainy: $t$ ratio $=-4.969, p<0.0001)$, and $P$. floribundum in the rainy season ( ratio $=-2.347, p=0.0215$ ) (Figure $2 \mathrm{a}$ ). $\mathrm{CP}$ was significantly higher under $H$. serratifolius in both the dry ( ratio $=-3579, p=0.0006)$ and rainy season $($ ratio $=-2.593$, $p=0.0114)$, and $S$. tubulosa in the rainy season ( $t$ ratio $=$ $-2.060, p=0.0428$ ).

Trre presence did not significantly affect NDF content in forage, but did affect ADF (chi-squared $=13.219, p=0.0002$ ). Forage under $H$ serratifolius had significantly lower ADF content then off the canopy in the dry season ( tratio $=2.437$,
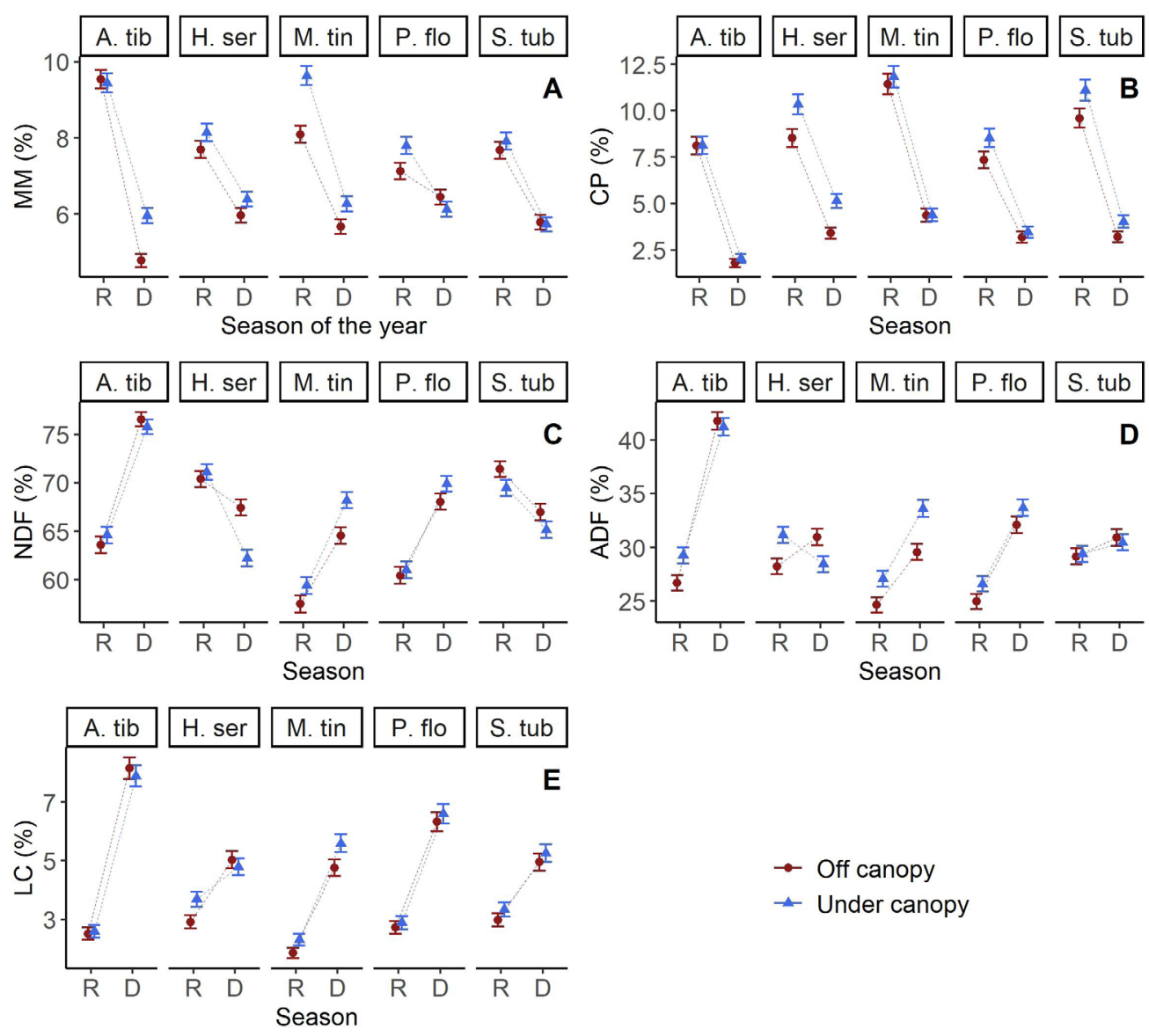

- Under canopy

Figure 2. Estimated marginal means and standard errors of models selected to explain the variance in nutritional properties of palisade grass (Urochloa brizantha) inside and outside the crown cover of isolated trees of five native species in four pastures in the dry and rainy season in northwestern Mato Grosso State, Brazil. A mineral matter (MM); B -crude protein (CP); C - neutral detergent fiber (NDF); D - acid detergent fiber (ADF); E - lignin content (LC). A. tib = Apeiba tibourbou; H. ser $=$ Handroanthus serratifolius; $\mathrm{M}$. tin = Maclura tinctoria; $\mathrm{P}$. flo = Platymiscium floribundum; $\mathrm{S}$. tub = Samanea tubulosa. Season: $\mathrm{R}=$ rainy; $\mathrm{D}=$ dry. This figure is in color in the electronic version. 
Table 1. Summary statistics of selected GLMM models for additive $(+)$ or interactive $(*)$ effects of tree presence, season and species on soil and forage attributes in northern Mato Grosso state, Brazil. GLMM adapted coefficient of determination $\left(R^{2}\right)$ of marginal $(m)$ and conditional $(c)$ terms and adjusted intra-class correlation (ICC ${ }_{\text {adj }}$ ) are shown. Model calculation for NDF and lignin was not possible due to some variance components being equal to zero.

\begin{tabular}{|c|c|c|c|}
\hline Selected models & $\mathbf{R}_{\mathrm{GLMM}(m)}^{2}$ & $\mathbf{R}_{\text {GLMM(c) }}^{2}$ & $\mathrm{ICC}_{\text {adj }}$ \\
\hline \multicolumn{4}{|c|}{ Soil } \\
\hline Phosphorus $\sim$ season*species & 0.56 & 0.649 & 0.202 \\
\hline Potassium $\sim$ tree $^{*}$ season ${ }^{*}$ species & 0.654 & 0.751 & 0.282 \\
\hline Calcium $\sim$ tree $^{*}$ season $^{*}$ species & 0.87 & 0.901 & 0.239 \\
\hline Magnesium $\sim$ tree + season + species & 0.703 & 0.733 & 0.101 \\
\hline Organic matter $\sim$ tree+season+species & 0.564 & 0.685 & 0.277 \\
\hline \multicolumn{4}{|c|}{ Forage } \\
\hline Mineral matter $\sim$ tree $^{*}$ season*species & 0.925 & 0.91 & 0.168 \\
\hline Crude protein $\sim$ tree $^{*}$ season ${ }^{*}$ species & 0.951 & 0.948 & 0.057 \\
\hline NDF $\sim$ tree*$^{*}$ season*species & - & - & - \\
\hline ADF $\sim$ tree*$^{*}$ season*species & 0.962 & 0.954 & 0.17 \\
\hline Lignin $\sim$ season*species & - & - & - \\
\hline
\end{tabular}

$p=0.0171)$ and higher in the rainy season $($ ratio $=-2.462, p=$ $0.0061)$. Significantly higher ADF was also observed under A. tibourbou in the rainy season ( $\mathrm{t}$ ratio $=-2.541, \mathrm{p}=0.0130$ ) and $M$. tinctoria in both seasons (dry: $\mathrm{t}$ ratio $=-3.839, \mathrm{p}=$ 0.0002 ; rainy $=-2.462, \mathrm{p}=0.0160$, Figure $2 \mathrm{~d}$ ).

\section{DISCUSSION}

Our results showed that native Amazonian tree species can have neutral or positive eefects on forage quality and soil fertility in agricultural landscapes that interact with seasonal and site-specific effects. Quantitative and qualitative responses of forage depend on the architecture of forage plants, the density and shading of tree canopies, and environmental factors such as soil fertility and moisture, (Jose et al. 2019). Several studies have demonstrated the benefits of natural or artificial shade for forage yield and quality (Andrade et al. 2004; Sousa et al. 2010; Pang et al. 2019a; Pang et al. 2019b; Pezzopane et al. 2019). Some forage species, including grasses and legumes commonly used in pastures across the Amazon basin, are shade tolerant, usually adjusting to decreased sunlight influx by devoting more primary production to leaf area than root matter (Andrade et al. 2004).

Our results suggest that the presence of native tree species could potentially mitigate forage quality decline in the dry season, as evidenced by the significantly higher contents of MM and CP in dry season forage under A. tibourbou and $M$. tinctoria. Handroanthus serratifolius in particular stood out as the forage under its canopy had higher levels of CP in both seasons, in addition to a reduced fiber content in the dry season, and overall higher K levels in the soil under the canopy, which was also found for $A$. tibourbou. Direct effects of trees on the microclimatic and edaphic factors depends primarily on the tree's ability of shading, which means covering a large area and allowing enough light simultaneously (Andrade et al. 2012). Therefore, allowing some level of tree shading in pastures as a drought mitigation practice, and also as a key source of protective shade, is widely desirable for sustainable tropical livestock systems (Chará et al. 2019; Gomes et al. 2019; Olival et al. 2020).

Overall, our best-fitting models suggested that most soil and forage variables responded to some extent to tree presence and seasonality, and also varied among the species. Yet, although we were able to observe some effects of tree presence on soil fertility and forage quality within species, our sampling design did not allow the identification of interspecific effects. All pastures were located in the same microregion, and were subject to the same climate, overall soil type and stocking rate, yet, as all focal trees of each species were aggregated in different pastures, the species effect was confounded with site effects such as different management practices, stocking rates and herd productivity, as well as soil and terrain specificities. Thus the differencial occurrence and magnitude of the effects of these native tree species on pastures should be elucidated in further studies using an appropriately replicated sampling design.

Species-specific traits generate distinct root exudation, microenvironments and litter quality that strongly influence the soil nutrient supply (Lambers et al. 2008). Higher contents of polyphenols can have a strong effect on litter quality (Lambers et al. 2008), which may be the case with $A$. tibourbou, as its leaves have high content of rosmarinic acid (Souza et al. 2012) and it had the largest effect on soil fertility, especially on K content. Apeiba tibourbou is commonly found in secondary forests across the Amazon, and probably prefers soils with higher fertility (Tavares et al. 2019). Hence, because of its nutrient requirement, it may recycle nutrients from deeper layers (Sileshi et al. 2014).

The effect of tree presence on forage quality may vary depending not only on tree characteristics but also on the forage species. Many grasses, such as Urochloa spp., can tolerate a reduction in light intensity up to 30 or $40 \%$ without 
affecting dry matter production (Xavier et al. 2014; Ledesma et al. 2017), which may explain the either neutral or positive effects of the trees on forage quality. The shade tolerance of different forage species is associated with adaptive mechanisms such as leaf area increase, allowing shaded pastures to sustain productivity at levels equivalent to pastures without shade (Araujo et al. 2020; Gomes et al. 2020). It is important to emphasize that all tree species were selected by farmers based on their experience and perception of non-negative influence on forage species.

Forage under $M$. tinctoria was the only with MM significantly higher than off canopy in both seasons. Litter from this species has an accelerated decomposition time and high potential for rapid nutrient incorporation into the soil, especially N, P, K, Ca and Mg (Silva 2016). Constant and abundant leaf production leads to greater nutrient cycling, offering optimal conditions for forage development, making pioneer species such as $M$. tinctoria good candidates for further studies on the strengthening of ecological processes for the improvement of silvopastoral systems (Parsons and Congdon 2008). The presence of $H$. serratifolius and S. tubulosa was associated with significantly higher CP in forage in both seasonsand the rainy season, respectively. Trees of Samanea, particularly $S$. saman and $S$. tubulosa, provide protective shade in pastures, produce palatable pods that are suitable as a dryseason feed supplementation and enhance grass production beneath their crown (Durr 2001; Andrade et al. 2012). We showed that forage under $S$. tubulosa has higher CP content, possibly due to higher nitrogen content in the ryzosphere and litter fall, because of its ability to symbiotically fix atmospheric nitrogen or unlock mineral nutrients through enhanced microbiome activities (Epihov et al. 2021).

The higher CP content in forage under $H$. serratifolius and S. tubulosa could be related to the larger size of forage-leaf cells and the higher amount of intracellular nutrients, including proteins, resulting from the greater cell volume as a response to higher moisture, stable temperature and light reduction (Sousa et al. 2010; Moreira et al. 2013). Also, forage plants under trees may be physiologically younger, since they have a higher proportion of green leaves, thereby extending the juvenile vegetative state and allowing the maintenance of higher metabolic levels for a longer period (Sousa et al. 2010). In addition, nitrogen-rich organic matter from litter of $\mathrm{N}$-fixing species, such as $S$. tubulosa, could explain a higher content of CP in forage under these trees (Ledesma et al. 2017). It is noteworthy, however, that, although forage CP under $H$. serratifolius and $S$. tubulosa was higher than off the canopy, the protein levels were still less than the minimum required for cattle (Valente et al. 2013), pointing to the importance of complementary measures to manage the livestock system.

The seasonality observed in some positive effects of the presence tree was probably related to the intensity and frequency of rainfall, as the effect of trees on forage quality and soil depends mainly on the weather conditions, which influence the decomposer biota and the quality of the organic matter offered by the trees, such as the $\mathrm{C} / \mathrm{N}$ ratio and lignin content (Prause and Lopes 2012; Machado et al. 2017). Deciduousness patterns of trees along the year may also affect forage quality and yield during dry seasons, which is a major challenge for the sustainability of livestock systems, as it implies supplementing animal diet at a high cost in order to spare pasture. The long-term effect of native tree species in minimizing forage loss during the dry season, as well as providers of supplemental fodder from their leaves and fruits is a promising line for further studies.

Tree and crown size might be an important factor determining forage and soil characteristics beneath canopies (Treydte et al. 2009) and also the chemical composition of leaves (Binkley and Giardina 1998). Considering the wide spectrum of tree functional traits, such as leaf lifespan, leaf composition, crown dimensions, vegetative and reproductive phenological patterns, further studies should also address diversified set of tree species in the pasture environment for functional complementarity.

The absence of significantly negative effects of the presence of trees in almost all cases is noteworthy, since cutting trees is a culturally widespread practice among cattle ranchers across the Amazon, which has increased the negative impacts of livestock, especially on soil fertility (Machado et al. 2017; Steingraber et al. 2018). The history of recent colonization of agricultural frontiers at the fringes of the Amazon biome is marked by high deforestation encouraged by governments and colonization companies, followed by livestock occupation (Godar et al. 2012). The extensive livestock systems have been established on the basis of slash and burn practices, and subsequent pasture degradation and mismanagement lead to productivity reduction and, eventually, to abandonment of the land. This is a very common condition in Brazil, where more than half of livestock production takes place on degraded pastures (Silva et al. 2017). Reintroducing the tree element in pastures in Brazil's arc of deforestation has the potential to contribute as a sustainable practice to restoring degraded pastures and improving soil quality and the quality and amount of forage, in addition to the adjustment of stocking rates to the actual carrying capacity of the pasture (Boval and Dixon 2012). The implementation of these types of silvopastoral systems is advancing across the Amazon region and can potentially support livestock intensification while benefitting ecosystem services (Gomes et al. 2020).

\section{CONCLUSIONS}

Our study complements the empirical knowledge of cattle farmers in the southwestern Brazilian Amazon about the silvopastoral benefits of five native Amazonian tree species. 
We observed some effects of the presence of common multipurpose tree species widely used in pastures in our study area regarding protecton against drought effects, enhancement of nutrient cycling and improvement of forage quality through higher mineral and protein content, as well as lower fiber content. The species with more significant positive effects were Apeiba tibourbou, Handroanthus serratifolius and Maclura tinctoria. Our results suggest that tree cover is a beneficial complementary strategy of pasture management. Contrary to cultural beliefs, our results showed practically no signs that the presence of trees impairs forage quality. Further studies using larger samples and site-independent designs should further assess the influence of the presence of these species on the pasture environment and their benefits for sustainable silvopastoral systems.

\section{ACKNOWLEDGMENTS}

We are very thankful to the farmers participating in our research program and to the editor and three anonymous reviewers for their bright contributions. We thank the students of the Universidade do Estado de Mato Grosso and the technicians of Instituto Ouro Verde. This work was supported by Fundo Amazônia, through the Banco Nacional de Desenvolvimento Econômico e Social (BNDES).

\section{REFERENCES}

Almeida, R.G.; de Andrade, C.M.S.; Paciullo, D.S.C.; Fernandes, P.C.C, Cavalcante, A.C.R.; Barbosa, R.A.; Valle, C.B. 2013. Brazilian agroforestry systems for cattle and sheep. Tropical Grasslands- Forrajes Tropicales, 1: 175-183.

Alvares, C.A.; Stape, J.L.; Sentelhas, P.C.; Gonçalves, J.L.M.; Sparovek, G. 2013. Köppen's climate classification map for Brazil. Meteorologische Zeitschrift, 22: 711-728.

Alvarez, F.; Casanoves, F. Suarez, J. C.; Pezo, D. 2021. The effect of different levels of tree cover on milkproduction in dual-purpose livestock systems in the humidtropics of the Colombian Amazon region. Agroforestry Systems, 95: 93-102.

Andrade, C.M.S.; Salman, A.K.D.; Oliveira, T.K. 2012. Guia Arbopasto: Manual de Identificação e Seleção de Espécies Arbóreas para Sistemas Silvipastoris. EMBRAPA, Rio Branco, 345p.

Andrade, C.M.S.; Valentim, J.F.; Carneiro, J.D.C.; Vaz, F.A. 2004. Crescimento de gramíneas e leguminosas forrageiras tropicais sob sombreamento. Pesquisa Agropecuária Brasileira, 39: 263-270.

AOAC. 2012. Official Methods of Analysis of AOAC international. 19th ed. AOAC International, Maryland, 3000p.

Araújo, R.A.; Rodrigues, R.C.; Costa, C.S.; Santos, F.N.S.; Lima, A.J.T.; Rodrigues, M.M. 2020. Dynamics and stability of Marandu grass tillers in monocrop systems and babassu palm silvopastoral systems. Acta Scientiarum Agronomy, 42: e42445.

Barrett, K.; Valentim, J.; Turner, B.L. 2013. Ecosystem services from converted land: The importance of tree cover in Amazonian pastures. Urban Ecosystems, 16: 573-591.
Bates D.; Maechler M.; Bolker B.; Walker S. 2015. Fitting linear mixed-effects models using lme4. Journal of Statistical Software, 67: 1-48. http://dx.doi.org/10.18637/jss.v067.i01

Bernardi, R.E.; Jonge, I.K.; Holmgren, M.T. 2016. Trees improve forage quality and abundance in South American subtropical grasslands. Agriculture, Ecosystems \& Environment, 16: 227-231.

Binkley, D.; Giardina, C. 1998. Why do tree species affect soils? The Warp and Woof of tree-soil interactions. Biogeochemistry, 42: 89-106.

Boval, M.; Dixon, R.M. 2012. The importance of grasslands for animal production and other functions: a review on management and methodological progress in the tropics. Animal, 6: 748-762.

Brancalion, P.H.S.; de Almeida, D.R.A.; Vidal, E.; Molin, P.G.; Sontag, V.E.; Souza, S.E.X.F.; Schulze, M.D. 2018. Fake legal logging in the Brazilian Amazon. Science Advances, 4: eaat1192.

Brooks, M.E.; Kristensen, K.; Benthem, K.J. van; Magnusson, A.; Berg, C.W.; Nielsen, A.; Skaug, H.J.; Machler, M.; Bolker, B.M. 2017. glmmTMB balances speed and flexibility among packages for zero-inflated generalized linear mixed modeling. The R Journal, 9: 378-400.

Burnham, K.P.; Anderson, D.R. 2002. Model Selection and Multimodel Inference: A Practical Information-theoretic Approach, 2nd ed. Springer, New York, 488p.

Carrilho, P.H.M.; Alonso, J.; Santos, L.D.T.; Sampaio, R.A. 2012. Vegetative and reproductive behavior of Brachiaria decumbens cv. Basilisk under different shade levels. Cuba Journal of Agricultural Science, 46: 85-90.

Carvalho, G.A.; Salman, A.K.D.; Cruz, P.G.; da Silva, F.R.F.; Halfen, J.; Schmitt, E. 2018. Relationship between thermal comfort indices and internal temperature of grazing lactating Holstein $x$ Gyr cows in western Amazonia. Acta Amazonica, 48: 191-196.

Carvalho, P.E.R. 2003. Espécies Arbóreas Brasileiras. 1st ed. Embrapa Informação Tecnológica, Brasília. 1040p.

Carvalho, P.E.R. 2007. Bordão-de-Velho (Samanea tubulosa). Circular Técnica \# 132. EMBRAPA Florestas, Colombo, 6p.

Chará, J.; Reyes, E.; Otte, J.; Peri, P.; Arce, E.; Scheider, F. 2019. Silvopastoral Systems and their Contribution to Improved Resource Use and Sustainable Development Goals: Evidence from Latin America. FAO/CIPAV/Agri Benchmark, Cali, 60p. (http://www. fao.org/3/ca2792en/ca2792en.pdf). Accessed on 08 Dec 2020.

Delgado, D.C.; Hera, R.; Cairo, J.; Ort, Y. 2014. Samanea saman, a multi-purpose tree with potentialities as alternative feed for animals of productive interest. Cuban Journal of Agricultural Science, 48: 205-212.

Devendra, C. 2014. Perspectives on the potential of silvopastoral systems. Agrotechnology, 3: 1-8. doi: 10.4172/2168-9881.1000117

Durr, P.A. 2001. The biology, ecology and agroforestry potential of the raintree, Samanea saman (Jacq.) Merr. Agroforestry Systems, 51: 223-237.

Embrapa. 2009. Manual de Análises Quimicas de Solos, Plantas e Fertilizantes. Embrapa Informação Tecnológica, Brasília. 627p.

England, J.R.; O'Grady, A.P.; Fleming, A.; Marais, Z.; Mendham, D. 2020. Trees on farms to support natural capital: An evidencebased review for grazed dairy systems. Science of the Total Environment, 704: e135345. 
Epihov, D.Z.; Saltonstall, K.; Batterman, S.A.; Hedin, L.O.; Hall, J.S.; van Breuguel, M.; Leake, J.R.; Beerling, D.J. 2021. Legumemicrobiome interactions unlock mineral nutrients in regrowing tropical forests. Proceedings of the National Academy of Sciences of the United States of America, 118: e2022241118.

FAO. 2012. Phenotipic characterization of animal genetic resources. Animal Production and Health Proceedings. n. 11. Rome, 142p. (www.fao.org/3/i2686e/i2686e00.pdf). Accessed on 09 Jul 2019.

Fox J.; Weisberg S. 2019 An $\{R\}$ Companion to Applied Regression. 3rd ed. Sage Publication, Oaks, 608p.

Godar J.; Tizado E.J.; Pokorny B. 2012. Who is responsible for deforestation in the Amazon? A spatially explicit analysis along the Transamazon Highway in Brazil. Forest Ecology and Management, 267: 58-73.

Frank, I.L. 1999. Principais Usos e Serviços de Árvores e Arbustos Promissores que Ocorrem em Pastagens no Estado do Acre. Comunicado Técnico \# 106, Embrapa, Brasília, 6p.

Gomes, J.E.; Fabis, M.H.M.; Penha, E.A.; Miranda, E.F.. 2003. Comparação da precisão de modelos hipsométricos ajustados com dados obtidos por meio do uso de prancheta dendrométrica e fita métrica em povoamentos florestais do gênero Eucalyptus na região do oeste do estado de São Paulo. Revista Científica Eletrônica de Engenharia Florestal, 2: 1-5. (http://www.faef. revista.inf.br/imagens_arquivos/arquivos_destaque/IWHDRe YfURU5iUQ_2013-4-24-12-26-0.pdf)

Gomes, F.J.; Pedreira, C.G.S.; Bosi, C.; Cavalli, J.; Holschuchm, S.G.; Mourão, G.B.; pereira, D.H.; Pedreira, B.C. 2019. Shading effects on marandu palisadegrass in a silvopastoral system: Plant morphological and physiological responses. Agronomy Journal, 111: 2332-2340.

Gomes, F.J.; Pedreira, B.C.; Santos, P.M.; Bosi, C.; Lulu, J.; Pedreira, C.G.S. 2020. Microclimate effects on canopy characteristics of shaded palisadegrass pastures in a silvopastoral system in the Amazon biome of central Brazil. European Journal of Agronomy 115. 126029

Harvey, C.A.; Villanueva, C.; Villacís J.; Chacon, M. 2005. Contribution of live fences to the ecological integrity of agricultural landscapes Agriculture, Ecosystems and Environment, 111: 200-230.

Harvey, C.A.; Haber, W.A. 1999. Remnant trees and the conservation of biodiversity in Costa Rican pastures. Agroforestry Systems, 44: 37-68.

IBGE. 2019. Censo agropecuário 2017: resultados definitivos. Instituto Brasileiro de Geografia e Estatística, Rio de Janeiro, 105p.

IBGE. 2012. Manual Técnico da Vegetação Brasileira. Manuais Técnicos em Geociências. Instituto Brasileiro de Geografia e Estatística, Rio de Janeiro, 271p.

IPCC. 2018. IPCC Special Report on the Impacts of Global Warming of $1.5^{\circ} \mathrm{C}$ Above Pre-industrial Levels and Related Global Greenhouse Gas EmissionPathways in the Context of Strengthening the Global Response. Summary for policy makers. United Nations Intergovernmental Panel on Climate Change, Geneva, 32p. (https://www.ipcc.ch/ sr15/chapter/spm/). Accessed on 18 Mar 2020

Jose, S.; Walter, D.; Mohan, K.B. 2019. Ecological considerations in sustainable silvopasture design and management. Agroforestry Systems, 93: 317-331.
Lambers, H.; Chapin, F.S.; Pons T.L. 2008. Plant Physiological Ecology, 2nd ed. Springer, New York. 605p.

Lasco, R.D.; Espaldon, M.L.O.; Habito, C.M.D. 2016. Smallholder farmers' perceptions of climate change and the roles of trees and agroforestry in climate risk adaptation: evidence from Bohol, Philippines. Agroforestry Systems, 90: 521-540.

Ledesma, L.M.; Arizala, J.A.; Hernández, W.A.B. 2017. Nutritional quality, degradability and methane production in silvopastoral arrangements. Agronomia Mesoamericana, 28: 371-387.

Lerner, A.M.; Rudel, T.K.; Schneider, L.C.; McGroddy, M.; Burbano, D.V.; Mena, C.F. 2015. The spontaneous emergence of silvopastoral landscapes in the Ecuadorian Amazon: patterns and processes. Regional Environmental Change, 15: 1421-1431.

Machado, M.R.; Camara, R.; Sampaio, P.T.B.; Pereira, M.G.; Ferraz, J.B.S. 2017. Land cover changes affect soil chemical attributes in the Brazilian Amazon. Acta Scientiarum Agronomy, 39: 385-391.

Martínez, J.; Cajas, Y.S.; León, J.D.; Osorio, N.W. 2014. Silvopastoral systems enhance soil quality in grasslands of Colombia. Applied and Environmental Soil Science, 2014: e359736.

Moreira, G.R.; Saliba, E.O.S.; Gonçalves, L.C.; Mauricio, R.M.; Sousa, L.F.; Rodriguez, N.M.; Lana, A.M.Q. 2013. Avaliação nutricional de fenos produzidos com Andropogon gayanus cv. Planaltina. Arquivo Brasileiro de Medicina Veterinária e Zootecnia, 65: 865-873.

Munroe, J.W.; Isaac, M.E. 2014. $\mathrm{N}_{2}$-fixing trees and the transfer of fixed-N for sustainable agroforestry: a review. Agronomy for Sustainable Development, 34: 417-427.

Nair, V.D.; Haile S.G..; Michel G.A.; Nair P.K.R. 2007. Environmental quality improvement of agricultural lands through silvopasture in southeastern United States. Scientia Agricola, 64: 513-519.

Nakagawa, S.; Johnson, P.C.D.; Schielzeth, H. 2017. The coefficient of determination R2 and intra-class correlation coefficient from generalized linear mixed-effects models revisited and expanded. Journal of the Royal Society Interface, 14: 20170213.

NRC. 2000. Nutrient Requirements of Beef Cattle. 7th ed. The National Academies Press, Washington D.C., 248p.

Olival, A.A.; Araújo, F.B.; Del Valle, T.A.A.; Osório, J.A.C.; Campana, M.; Morais, J.P.G. 2020. Impact of an agroforestry system on grazing, ruminating, and resting behaviors of dairy cows. Iranian Journal of Applied Animal Science, 10: 45-50.

Oliveira, A.H.; Silva, M.A.; Silva, M.L.N.; Avanzi, J.C.; Curi, N.; Lima, G.C.; Pereira, P.H. 2012. Caracterização ambiental e predição dos teores de matéria orgânica do solo na subBacia do Salto, Extrema, MG. Semina: Ciências Agrárias, 33: 143-154.

Oliveira, R.E.; Carvalhaes, M.A. 2016. Agroforestry as a tool for restoration in Atlantic Forest: can we find multipurpose species? Rio de Janeiro. Oecologia Australis, 20: 425-435.

Oliveira, R.E.; Carvalhaes, M.A. 2016. Agroforestry as a tool for restoration in Atlantic Forest: can we find multipurpose species? Oecologia Australis, Rio de Janeiro, 20: 425-435.

Pang, K.; Van Sambeek, J.W.; Navarrete-Tindall, N.E.; Lin, C.; Jose, S.; Garret, H.E. 2019a. Responses of legumes and grasses to non-, moderate, and dense shade in Missouri, USA. II. Forage quality and its species-level plasticity. Agroforestry Systems, 93: 25-38. 
Pang, K.; Van Sambeek, J.W.; Navarrete-Tindall, N.E.; Lin, C.; Jose, S.; Garret, H.E. 2019b. Responses of legumes and grasses to non-, moderate, and dense shade in Missouri, USA. I. Forage yield and its species-level plasticity. Agroforestry Systems, 93: 11-24.

Parsons, S.; Congdon, R. 2008. Plant litter decomposition and nutrient cycling in north Queensland tropical rain-forest communities of differing successional status. Journal of Tropical Ecology, 24: 317-327.

Pezzopane, J.R.M.; Bernardi, A.C.C.; Bosi, C.; Oliveira, P.P.A.; Marconato, M.H.; Pedroso, A.F.; Esteves, S.N. 2019. Forage productivity and nutritive value during pasture renovation in integrated systems. Agroforestry Systems, 93: 39-49.

Pinho, R.C.; Miller, R.P.; Alfaia, S.S. 2012. Agroforestry and the improvement of soil fertility: A view from Amazonia. Applied and Environmental Soil Science. 2012: 616383

Prause, J.; Lopez, C.F. 2012. Concentración estacional de micronutrientes em hojas de cuatro especies florestales del Parque Chaqueno, Argentina. Revista de Biologia Tropical, 60: 1109-1116.

R Core Team, 2019. R: A language and environment for statistical computing. Vienna.

Rey, A.C.; Díaz, H.R. 2017. Características químicas del suelo, producción forrajera y densidad poblacional de lombrices en un sistema silvopastoril en la zona Huetar Norte de Costa Rica. Tecnología en Marcha, 28: 91-104.

Rożek, K.; Rola, K.; Błaszkowski, J.; Leski, T.; Zubek, S. 2020. How do monocultures of fourteen forest tree species affect arbuscular mycorrhizal fungi abundance and species richness and composition in soil?. Forest Ecology and Management, 465: 118091

Santos, D.C.; Guimarães Júnior, R.; Vilela, L.; Pulrolnik, K.; Bufon, V.B.; França, F.S. 2016. Forage dry mass accumulation and structural characteristics of Piatá grass in silvopastoral systems in the Brazilian savannah. Agriculture, Ecosystems \& Environment, 233: 16-24.

Sarvade, S.; Gautan, D.S.; Upadhyay, V.B.; Sahu, R..K. Shrivastava, A.K.; Kaushal, R., Singh, R.; Yewale, A.G. 2019. Agroforestry and soil health: an overview. In. Inder, D. (Ed.). Agroforestry for Climate Resilience and Rural Livelihood. Scientific Publishers, Jodhpur, p. 276-297.

Schroth, G.; Sinclair, F.L. 2003. Impacts of trees on the fertility of agricultural soils. In: Schroth, G.; Sinclair, F.L. (Ed.). Trees, Crops and Soil Fertility: Concepts and Research Methods. CABI Publishing, Bristol, p.1-11.

Sileshi, G.W.; Mafongoya, P.L.; Akinnifesi, F.K.; Phiri, E.; Chirwa, P.; Beedv, T.; et al. 2014. Agroforestry: fertilizer trees. Encyclopedia of Agriculture and Food Systems, 2014: 222-234.

Silva, R.O.; Barioni, L.G.; Hall, J.A.; Moretti, A.C.; Veloso, R.F.; Alexander, P.; Crespolini, M.; Moran, D. 2017. Sustainable intensification of Brazilian livestock production through optimized pasture restoration. Agricultural Systems, 153: 201-211.
Silva, S.G. 2016. Decomposiçāo da biomassa foliar e liberaçāo de nutrientes envolvendo espécies arbóreas nativas em sistemas agroflorestal biodiverso. Master's dissertation, Universidade Federal de Grande Dourados, Brazil. 42p. (https://repositorio. ufgd.edu.br/jspui/handle/prefix/1460). Accessed on 10 Jul 2019.

Sousa, L.F.; Maurício, R.M.; Moreira, G.R.; Gonçalves, L.C.; Borges, I.; Pereira, L.G.R. 2010. Nutritional evaluation of "Braquiarão" grass in association with "Aroeira" trees in a silvopastoral system. Agroforestry Systems, 79: 189-199.

Souza, S.M.M.; Couto, R.; Gil, E.S.; Morais, S.S. 2012. In vitro antioxidant activity of Apeiba tibourbou Aubl. (Tiliaceae): A powerful antioxidant source of rosmarinic acid. Journal of Pharmacy Research, 5: 1414-1417.

Steingraber, R.; Kanoppa, A.P.; Caetano, J.F. 2018. Environmental services as an endogenous development strategy: an alternative to deforestation in the state of Acre, Brazil. Acta Scientiarum. Human and Social Sciences, 40: e36473.

Tavares, L.S.; Valadão, F.C.A.; Weber O.L.S.; Espinosa, M.M. 2019. Análise multivariada de espécies florestais nativas em relação aos atributos químicos e texturais do solo na regiāo de CotriguaçuMT. Ciência Florestal, 29: 281-291.

Treydte, A.C.; Grant, C.C.; Jeltsch, F. 2009. Tree size and herbivory determine below-canopy grass quality and species composition in savannahs. Biodiversity and Conservation, 18: 3989-4002.

Valente, E.E.L.; Paulino, M.F.; Detmann, E.; Filho, S.C.V.; Cardenas, J.E.G.; Dias, I.F.T. 2013. Requirement of energy and protein of beef cattle on tropical pasture. Acta Scientiarum. Animal Sciences, 35: 417-424.

Van Soest, P.J.; Robertson, J.B.; Lewis, B.A. 1991. Methods for dietary fiber, neutral detergent fiber, and nonstarch polysaccharides in relation to animal nutrition. Journal of Dairy Science, 74: 3583-3597.

Vergne, D.C.; Almeida H.S.; Campos C.C.F.; Martins, N.S.; Ramos, F.N. 2016. Isolated trees with high crown coverage and densities increase pasture seed rain. Acta Botanica Brasilica, 30: 486-494.

West, J.W. 2003. Effects of heat-stress on production in dairy cattle. Journal of Dairy Science, 86: 2131-2144.

Xavier, D.F.; Silva, F.J.; Paciullo, D.S.C.; Urquiaga, S.; Alves, B.J.R.; Boddey, R.M. 2014. Nitrogen cycling in a Brachiaria-based silvopastoral system in the Atlantic forest region of Minas Gerais, Brazil. Nutrient Cycling in Agroecosystems, 99: 45-62.

RECEIVED: $14 / 12 / 2020$

ACCEPTED: 04/08/2021

ASSOCIATE EDITOR: Tomas F. Domingues 
SUPPLEMENTARY MATERIAL (only available in the electronic version)

Olival $e t$ al. Effect of Amazonian tree species on soil and pasture quality in silvopastoral systems
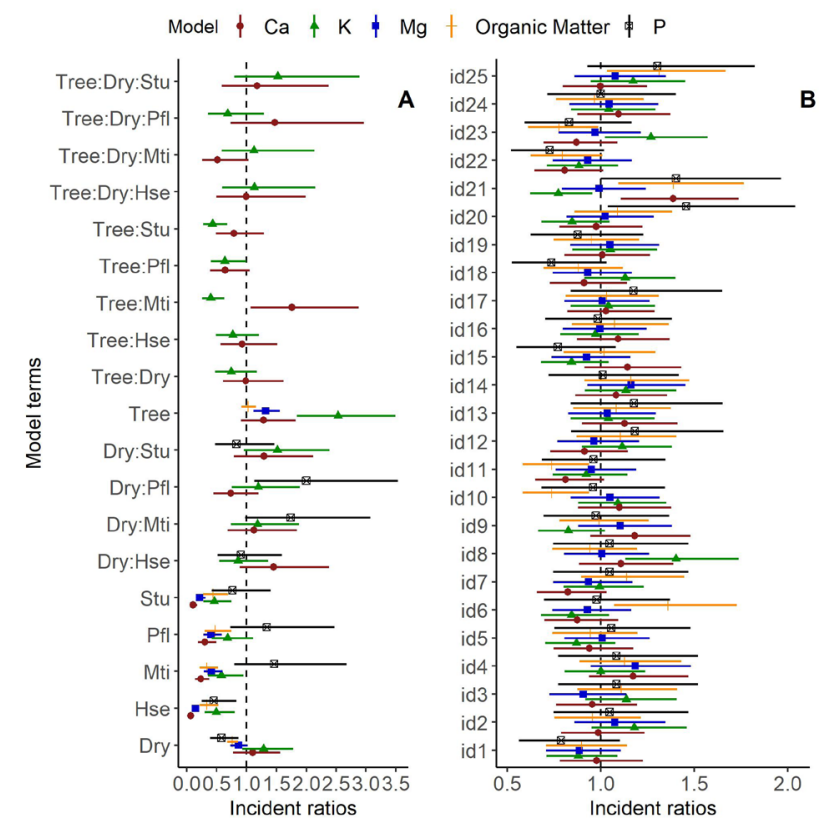

Figure S1. Estimates and 95\% confidence intervals of fixed (A) and random (B) terms of all selected models of soil fertility responses to tree presence in silvopastoral systems in northern Mato Grosso, Brazil. The vertical dashed line represents the intercept term, which is the sampling outside the crown area for Apeiba tibourbou (id16:id20) in the rainy season for A, and the average intercept of all individual trees sampled for B. Hse = Handroanthus serratifolius (id6:id10); Mti = Maclura tinctoria (id21:id25); Pfl = Platymiscium floribundum (id1:id5); Stu = Samanea tubulosa (id11:id15).
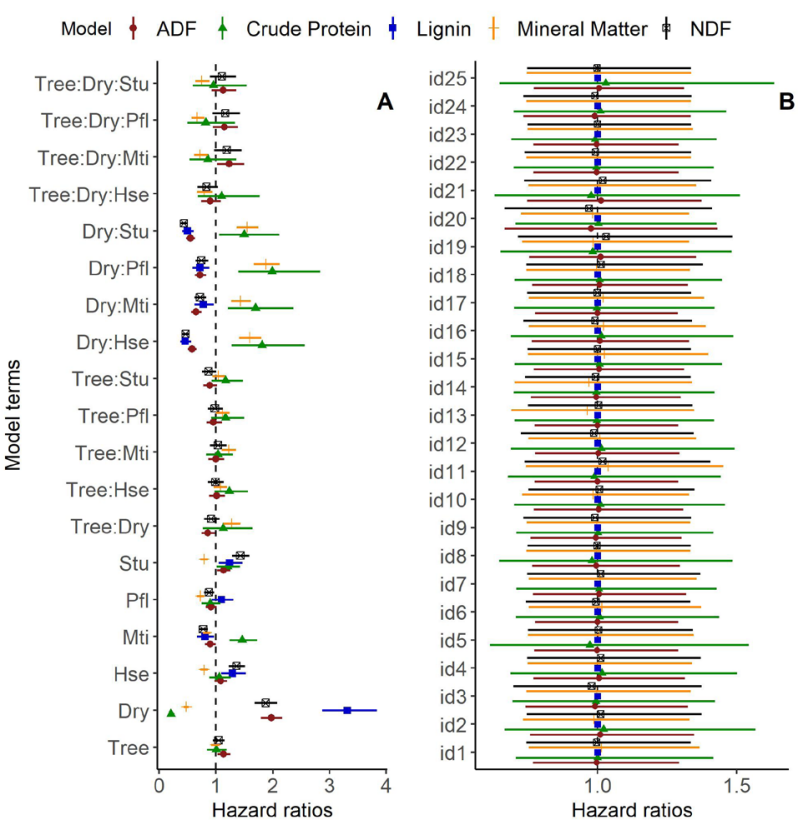

Figure S2. Estimates and 95\% confidence intervals of fixed (a) and random (b) terms of all selected models of forage quality responses to tree presence in silvopastoral systems in northern Mato Grosso, Brazil. The vertical dashed line represents the intercept term, which is the sampling outside the crown area for Apeiba tibourbou (id16:id20) in the rainy season for A, and the average intercept of all individual trees sampled for B. Hse = Handroanthus serratifolius (id6:id10); $\mathrm{Mti}=$ Maclura tinctoria (id21:id25); Pfl = Platymiscium floribundum (id1:id5); Stu = Samanea tubulosa (id11:id15).

Table S1. Functional and silvicultural information on the targeted tree species for soil and forage analysis in the north region of Mato Grosso state, Brazil. N-fixing = legume species able to symbiotically fix nitrogen.

\begin{tabular}{lcccccc}
\hline Species & N-fixing & Deciduousness & Growth & Total adult height $(\mathbf{m})$ & Canopy shape & Canopy density \\
\hline Apeiba tibourbou & No & Evergreen & Fast & $10-20$ & Flabeliform & Low \\
Handroanthus serratifolius & No & Deciduous & Medium & $>20$ & Cylindrical & Low \\
Maclura tinctoria & No & Semideciduous & Fast & $10-20$ & Horizontally elliptical & Very low \\
Platymiscium floribundum & Yes & Evergreen & Slow & $>20$ & Cylindrical & Low \\
Samanea tubulosa & Yes & Deciduous & Medium & $10-20$ & Flabeliform & Low \\
\hline
\end{tabular}

Source: Adapted from Carvalho (2003).

Table S2. Height, diameter at breast height (DBH) and canopy area of five native species targeted for forage and soil analysis in pastures in northern Mato Grosso state, Brazil. Values are the mean and standard deviation of five trees per species.

\begin{tabular}{lccc}
\hline Species & Total height $(\mathbf{m})$ & DBH $(\mathbf{c m})$ & Canopy area $\left(\mathbf{m}^{2}\right)$ \\
\hline Handroanthus serratifolius & $26.8 \pm 3.9$ & $34.5 \pm 12.0$ & $58.8 \pm 25.9$ \\
Samanea tubulosa & $18.4 \pm 1.6$ & $17.5 \pm 2.7$ & $48.8 \pm 17.7$ \\
Apeiba tibourbou & $22.6 \pm 6.0$ & $74.9 \pm 18.3$ & $144.3 \pm 37.4$ \\
Maclura tinctoria & $18.7 \pm 2.6$ & $65.9 \pm 8.9$ & $133.9 \pm 79.0$ \\
Platymiscium floribundum & $22.2 \pm 5.2$ & $40.4 \pm 28.0$ & $100.3 \pm 66.7$ \\
\hline
\end{tabular}


Table S3. Akaike`s Information Criterion (AIC) parameters for predictors of forage quality under and off the canopy of native species in northern Mato Grosso, Brazil. Generalized linear mixed models (GLMM) fitted using the gamma distribution family, with linklog, and random intercept structure of individual grouping. $+=$ additive term; ${ }^{*}=$ interaction term

\begin{tabular}{|c|c|c|c|c|c|c|c|}
\hline $\begin{array}{l}\text { Dependent variable / } \\
\text { Model specification }\end{array}$ & df & AIC & $\Delta \mathrm{AIC}$ & Weight & Likelihood & $\mathbf{R}_{\text {GLMM(m) }}^{2}$ & $\mathrm{R}_{\text {GLMM(C) }}^{2}$ \\
\hline \multicolumn{8}{|c|}{ Phosphorus (mg dm${ }^{-3}$ ) } \\
\hline tree + season + species & 9 & 334.4 & 7.0 & $2.81 \mathrm{E}-02$ & $3.04 \mathrm{E}-02$ & 0.49 & 0.59 \\
\hline tree + season & 5 & 348.5 & 21.0 & $2.48 \mathrm{E}-05$ & 2.69E-05 & 0.05 & 0.46 \\
\hline tree + species & 8 & 344.0 & 16.6 & $2.33 \mathrm{E}-04$ & $2.52 \mathrm{E}-04$ & 0.43 & 0.52 \\
\hline season + species & 8 & 333.5 & 6.1 & 4.48E-02 & 4.85E-02 & 0.49 & 0.58 \\
\hline species & 7 & 343.2 & 15.7 & $3.57 \mathrm{E}-04$ & $3.87 \mathrm{E}-04$ & 0.42 & 0.51 \\
\hline tree $^{*}$ season* $^{*}$ species & 22 & 338.4 & 11.0 & $3.86 \mathrm{E}-03$ & 4.19E-03 & 0.59 & 0.68 \\
\hline tree ${ }^{*}$ season & 6 & 350.5 & 23.0 & $9.14 \mathrm{E}-06$ & 9.91E-06 & 0.05 & 0.46 \\
\hline tree* species & 12 & 348.4 & 21.0 & $2.56 \mathrm{E}-05$ & $2.78 \mathrm{E}-05$ & 0.46 & 0.55 \\
\hline season*species & 12 & 327.4 & 0.0 & $9.23 \mathrm{E}-01$ & $1.00 \mathrm{E}+00$ & 0.56 & 0.65 \\
\hline tree & 4 & 357.9 & 30.4 & $2.26 \mathrm{E}-07$ & $2.45 \mathrm{E}-07$ & 0.00 & 0.40 \\
\hline season & 4 & 347.4 & 20.0 & $4.26 \mathrm{E}-05$ & 4.61E-05 & 0.04 & 0.46 \\
\hline Intercept only & 3 & 356.9 & 29.5 & $3.71 \mathrm{E}-07$ & 4.02E-07 & 0.00 & 0.39 \\
\hline \multicolumn{8}{|c|}{ Potassium $\left(\mathrm{mg} \mathrm{dm}^{-3}\right)$} \\
\hline tree + season + species & 9 & 1028.2 & 27.8 & $9.23 \mathrm{E}-07$ & $9.23 \mathrm{E}-07$ & 0.47 & 056 \\
\hline tree + season & 5 & 1036.7 & 36.3 & $1.30 \mathrm{E}-08$ & 1.30E-08 & 0.13 & 0.45 \\
\hline tree + species & 8 & 1037.4 & 37.0 & $9.12 \mathrm{E}-09$ & $9.12 \mathrm{E}-09$ & $0 . .42$ & 0.50 \\
\hline season + species & 8 & 1043.8 & 43.4 & $3.85 \mathrm{E}-10$ & $3.85 \mathrm{E}-10$ & 0.42 & 0.50 \\
\hline species & 7 & 1049.8 & 49.4 & $1.92 \mathrm{E}-11$ & $1.92 \mathrm{E}-11$ & 0.38 & 0.45 \\
\hline tree*season*species & 22 & 1000.4 & 0.0 & $1.00 \mathrm{E}+00$ & $1.00 \mathrm{E}+00$ & 0.65 & 0.75 \\
\hline tree*season & 6 & 1034.3 & 33.9 & 4.34E-08 & 4.34E-08 & 0.15 & 0.47 \\
\hline tree $^{*}$ species & 12 & 1025.2 & 24.7 & $4.24 \mathrm{E}-06$ & 4.24E-06 & 0.51 & 0.60 \\
\hline season*species & 12 & 1038.8 & 38.4 & 4.62E-09 & 4.62E-09 & 0.49 & 0.57 \\
\hline tree & 4 & 1046.1 & 45.6 & $1.23 \mathrm{E}-10$ & $1.23 \mathrm{E}-10$ & 0.08 & 0.39 \\
\hline season & 4 & 1054.2 & 53.7 & $2.15 \mathrm{E}-12$ & $2.15 \mathrm{E}-12$ & 0.04 & 0.36 \\
\hline Intercept only & 3 & 1060.1 & 59.7 & 1.09E-13 & $1.09 \mathrm{E}-13$ & 0.00 & 0.32 \\
\hline \multicolumn{8}{|c|}{ Calcium $\left(\mathrm{cmol}_{c} \mathrm{dm}^{-3}\right)$} \\
\hline tree + season + species & 9 & 214.5 & 5.0 & $6.91 \mathrm{E}-02$ & $8.14 \mathrm{E}-02$ & 0.83 & 0.86 \\
\hline tree + season & 5 & 249.0 & 39.5 & 2.21E-09 & 2.60E-09 & 0.03 & 0.66 \\
\hline tree + species & 8 & 217.4 & 7.9 & $1.61 \mathrm{E}-02$ & $1.89 \mathrm{E}-02$ & 0.82 & 0.85 \\
\hline season + species & 8 & 220.9 & 11.4 & $2.82 \mathrm{E}-03$ & 3.33E-03 & 0.81 & 0.84 \\
\hline species & 7 & 223.2 & 13.7 & $8.77 \mathrm{E}-04$ & $1.03 \mathrm{E}-03$ & 0.81 & 0.84 \\
\hline tree*season*species & 22 & 209.5 & 0.0 & 8.49E-01 & $1.00 \mathrm{E}+00$ & 0.87 & 0.90 \\
\hline tree ${ }^{*}$ season & 6 & 250.9 & 41.4 & $8.70 \mathrm{E}-10$ & 1.03E-09 & 0.03 & 0.66 \\
\hline tree* species & 12 & 219.1 & 9.6 & $7.08 \mathrm{E}-03$ & $8.34 \mathrm{E}-03$ & 0.83 & 0.86 \\
\hline season*species & 12 & 215.0 & 5.5 & $5.54 \mathrm{E}-02$ & $6.53 \mathrm{E}-02$ & 0.84 & 0.87 \\
\hline tree & 4 & 251.7 & 42.2 & $5.93 \mathrm{E}-10$ & $6.99 \mathrm{E}-10$ & 0.02 & 0.65 \\
\hline season & 4 & 256.1 & 46.6 & $6.59 \mathrm{E}-11$ & 7.77E-11 & 0.01 & 0.64 \\
\hline Intercept only & 3 & 258.1 & 48.6 & $2.41 \mathrm{E}-11$ & $2.84 \mathrm{E}-11$ & 0.00 & 0.63 \\
\hline \multicolumn{8}{|c|}{ Magnesium $\left(\mathrm{cmol}_{\mathrm{c}} \mathrm{dm}^{-3}\right)$} \\
\hline tree + season + species & 9 & 88.6 & 0.0 & $6.01 \mathrm{E}-01$ & $1.00 \mathrm{E}+00$ & 0.70 & 0.73 \\
\hline tree + season & 5 & 115.4 & 26.8 & $8.94 \mathrm{E}-07$ & $1.49 \mathrm{E}-06$ & 0.05 & 0.53 \\
\hline tree + species & 8 & 89.6 & 1.0 & $3.62 \mathrm{E}-01$ & $6.03 \mathrm{E}-01$ & 0.70 & 0.73 \\
\hline season + species & 8 & 96.4 & 7.8 & $1.19 \mathrm{E}-02$ & 1.97E-02 & 0.68 & 0.70 \\
\hline species & 7 & 97.6 & 9.0 & $6.57 \mathrm{E}-03$ & 1.09E-02 & 0.66 & 0.69 \\
\hline tree ${ }^{*} \operatorname{season}^{*}$ species & 22 & 104.0 & 15.4 & $2.72 \mathrm{E}-04$ & 4.53E-04 & 0.74 & 0.77 \\
\hline tree*season & 6 & 116.0 & 27.4 & $6.58 \mathrm{E}-07$ & $1.09 \mathrm{E}-06$ & 0.06 & 0.53 \\
\hline tree*species & 12 & 96.0 & 7.4 & $1.49 \mathrm{E}-02$ & 2.47E-02 & 0.70 & 0.73 \\
\hline season*species & 12 & 101.5 & 12.9 & $9.34 \mathrm{E}-04$ & $1.56 \mathrm{E}-03$ & 0.68 & 0.71 \\
\hline tree & 5 & 99.5 & 10.9 & $2.57 \mathrm{E}-03$ & 4.27E-03 & 0.06 & 0.44 \\
\hline season & 4 & 125.3 & 36.7 & 6.34E-09 & 1.06E-08 & 0.01 & 0.48 \\
\hline Intercept only & 3 & 126.5 & 37.9 & 3.54E-09 & 5.90E-09 & 0.00 & 0.47 \\
\hline
\end{tabular}


Table S3. Continued

\begin{tabular}{|c|c|c|c|c|c|c|c|}
\hline $\begin{array}{l}\text { Dependent variable / } \\
\text { Model specification }\end{array}$ & df & AIC & $\triangle \mathrm{AIC}$ & Weight & Likelihood & $\mathbf{R}_{\text {GLMM(m) }}^{2}$ & $\mathrm{R}_{\text {GLMM(C) }}^{2}$ \\
\hline \multicolumn{8}{|c|}{ Organic matter $\left(\mathrm{g} \mathrm{kg}^{-1}\right)$} \\
\hline tree + season + species & 9 & 713.2 & 1.8 & 2.67E-01 & 3.99E-01 & 0.56 & 0.68 \\
\hline tree + season & 5 & 721.3 & 10.0 & $4.58 \mathrm{E}-03$ & $6.87 \mathrm{E}-03$ & 0.08 & 0.51 \\
\hline tree + species & 8 & 729.0 & 17.6 & $1.00 \mathrm{E}-04$ & 1.50E-04 & 0.51 & 0.63 \\
\hline season + species & 8 & 711.4 & 0.0 & $6.68 \mathrm{E}-01$ & $1.00 \mathrm{E}+00$ & 0.56 & 0.68 \\
\hline species & 7 & 727.1 & 15.7 & $2.55 \mathrm{E}-04$ & $3.82 \mathrm{E}-04$ & 0.51 & 0.62 \\
\hline tree $^{*}$ season $^{*}$ species & 22 & 720.1 & 8.7 & $8.46 \mathrm{E}-03$ & 1.27E-02 & 0.61 & 0.74 \\
\hline tree ${ }^{*}$ season & 6 & 723.3 & 11.9 & $1.71 \mathrm{E}-03$ & $2.57 \mathrm{E}-03$ & 0.08 & 0.51 \\
\hline tree ${ }^{*}$ species & 12 & 725.3 & 13.9 & $6.38 \mathrm{E}-04$ & $9.56 \mathrm{E}-04$ & 0.56 & 0.67 \\
\hline season*species & 12 & 717.1 & 5.7 & 3.83E-02 & $5.74 \mathrm{E}-02$ & 0.57 & 0.69 \\
\hline tree & 4 & 737.7 & 26.3 & $1.31 \mathrm{E}-06$ & 1.96E-06 & 0.00 & 0.44 \\
\hline season & 4 & 719.5 & 8.1 & 1.17E-02 & 1.76E-02 & 0.08 & 0.51 \\
\hline Intercept only & 3 & 735.7 & 24.4 & $3.40 \mathrm{E}-06$ & 5.09E-06 & 0.00 & 0.44 \\
\hline
\end{tabular}

The rows in bold indicate the best-fitting models with the lowest $\mathrm{AIC}$ value or $\triangle \mathrm{AIC}<2$. $\mathrm{df}=$ degrees of freedom; AIC: = Akaike's Information Criterion; $\triangle \mathrm{AIC}$ $=$ difference in AIC between the given model and the model with the lowest AIC score; Weight = Akaike weight showing the relative support for each model; Likelihood = the likelihood of the model, an indicator of fit; $R_{G L M M(m)}^{2}=$ marginal coefficient of determination; $\mathrm{R}^{2}{ }_{\mathrm{GLMM}(c)}=$ conditional coefficient of determination.

Table S4. Akaike`s Information Criterion (AIC) parameters for predictors of forage quality under and off the canopy of native species in northern Mato Grosso, Brazil. Generalized linear mixed models (GLMM) fitted using beta distribution family, with link logit, and random intercept structure of individual grouping.

\begin{tabular}{|c|c|c|c|c|c|c|}
\hline $\begin{array}{l}\text { Response variable/ } \\
\text { Model specification }\end{array}$ & df & AIC & $\triangle \mathrm{AIC}$ & Weight & Likelihood & Pseudo $\mathrm{R}^{2}$ \\
\hline \multicolumn{7}{|c|}{ Mineral matter (\%) } \\
\hline tree + season + species & 9 & -684.2 & 62.6 & $2.55 \mathrm{E}-14$ & $2.55 \mathrm{E}-14$ & 0.75 \\
\hline tree + season & 5 & -680.0 & 66.9 & $3.04 \mathrm{E}-15$ & $3.04 \mathrm{E}-15$ & 0.70 \\
\hline tree + species & 8 & -555.0 & 191.9 & $2.19 \mathrm{E}-42$ & 2.19E-42 & 0.06 \\
\hline season + species & 8 & -675.8 & 71.0 & $3.80 \mathrm{E}-16$ & $3.80 \mathrm{E}-16$ & 0.73 \\
\hline species & 7 & -554.2 & 192.7 & $1.45 \mathrm{E}-42$ & $1.45 \mathrm{E}-42$ & 0.03 \\
\hline tree*season*species & 22 & -746.8 & 0.0 & $1.00 \mathrm{E}+00$ & $1.00 \mathrm{E}+00$ & 0.92 \\
\hline tree*season & 6 & -678.0 & 68.8 & $1.12 \mathrm{E}-15$ & $1.12 \mathrm{E}-15$ & 0.70 \\
\hline tree $^{*}$ species & 12 & -548.5 & 198.4 & $8.35 \mathrm{E}-44$ & $8.35 \mathrm{E}-44$ & 0.07 \\
\hline season*species & 12 & -719.5 & 27.3 & 1.17E-06 & 1.17E-06 & 0.84 \\
\hline tree & 4 & -560.8 & 186.0 & 4.03E-41 & 4.03E-41 & 0.03 \\
\hline season & 4 & -673.1 & 73.7 & $9.73 \mathrm{E}-17$ & $9.73 \mathrm{E}-17$ & 0.68 \\
\hline Intercept only & 3 & -560.1 & 186.7 & $2.90 \mathrm{E}-41$ & $2.90 \mathrm{E}-41$ & 0.07 \\
\hline \multicolumn{7}{|c|}{ Crude protein (\%) } \\
\hline tree + season + species & 9 & -606.7 & 12.4 & 1.99E-03 & $2.04 \mathrm{E}-03$ & 0.88 \\
\hline tree + season & 5 & -572.4 & 46.7 & 7.13E-11 & 7.34E-11 & 0.91 \\
\hline tree + species & 8 & -400.5 & 218.5 & $3.45 \mathrm{E}-48$ & $3.55 E-48$ & 0.10 \\
\hline season + species & 8 & -597.2 & 21.9 & $1.71 \mathrm{E}-05$ & $1.75 \mathrm{E}-05$ & 0.87 \\
\hline species & 7 & -400.9 & 218.1 & 4.19E-48 & $4.31 \mathrm{E}-48$ & 0.09 \\
\hline tree*season*species & 22 & -619.1 & 0.0 & $9.72 \mathrm{E}-01$ & $1.00 \mathrm{E}+00$ & 0.92 \\
\hline tree*season & 6 & -570.8 & 48.2 & $3.26 \mathrm{E}-11$ & $3.36 \mathrm{E}-11$ & 0.91 \\
\hline tree ${ }^{*}$ species & 12 & -393.5 & 225.6 & $1.01 \mathrm{E}-49$ & $1.04 \mathrm{E}-49$ & 0.11 \\
\hline season*species & 12 & -611.8 & 7.3 & $2.57 \mathrm{E}-02$ & $2.65 \mathrm{E}-02$ & 0.89 \\
\hline tree & 4 & -396.3 & 222.8 & 4.12E-49 & 4.24E-49 & 0.01 \\
\hline season & 4 & -564.0 & 55.0 & $1.08 \mathrm{E}-12$ & $1.12 \mathrm{E}-12$ & 0.89 \\
\hline Intercept only & 3 & -396.9 & 222.1 & $5.72 \mathrm{E}-49$ & $5.88 \mathrm{E}-49$ & 0.10 \\
\hline \multicolumn{7}{|c|}{ Neutral detegernt fiber (\%) } \\
\hline tree + season + species & 9 & -328.8 & 140.0 & 4.06E-31 & 4.06E-31 & 0.37 \\
\hline tree + season & 5 & -303.6 & 165.2 & $1.37 \mathrm{E}-36$ & $1.37 \mathrm{E}-36$ & 0.31 \\
\hline tree + species & 8 & -314.5 & 154.2 & $3.23 E-34$ & $3.23 \mathrm{E}-34$ & 0.26 \\
\hline season + species & 8 & -330.8 & 138.0 & 1.10E-30 & 1.10E-30 & 0.37 \\
\hline
\end{tabular}


Table S4. Continued

\begin{tabular}{|c|c|c|c|c|c|c|}
\hline $\begin{array}{l}\text { Response variable/ } \\
\text { Model specification }\end{array}$ & df & AIC & $\triangle \mathrm{AIC}$ & Weight & Likelihood & Pseudo $\mathrm{R}^{2}$ \\
\hline species & 7 & -316.5 & 152.2 & $8.76 \mathrm{E}-34$ & $8.77 E-34$ & 0.26 \\
\hline tree*season*species & 22 & -468.7 & 0.0 & $9.99 \mathrm{E}-01$ & $1.00 \mathrm{E}+00$ & 0.90 \\
\hline tree*season & 6 & -301.8 & 167.0 & $5.51 \mathrm{E}-37$ & $5.52 \mathrm{E}-37$ & 0.32 \\
\hline tree $^{*}$ species & 12 & -310.6 & 158.2 & $4.45 \mathrm{E}-35$ & $4.46 \mathrm{E}-35$ & 0.29 \\
\hline season*species & 12 & -454.3 & 14.4 & 7.37E-04 & 7.38E-04 & 0.83 \\
\hline tree & 4 & -292.8 & 176.0 & $6.19 E-39$ & $6.19 \mathrm{E}-39$ & 0.29 \\
\hline season & 4 & -305.6 & 163.2 & $3.71 \mathrm{E}-36$ & $3.72 \mathrm{E}-36$ & 0.31 \\
\hline Intercept only & 3 & -294.8 & 174.0 & $1.68 \mathrm{E}-38$ & $1.68 \mathrm{E}-38$ & 0.29 \\
\hline \multicolumn{7}{|c|}{ Acid detergent fiber (\%) } \\
\hline tree + season + species & 9 & -400.1 & 89.2 & $4.20 \mathrm{E}-20$ & $4.20 \mathrm{E}-20$ & 0.59 \\
\hline tree + season & 5 & -372.8 & 116.5 & $4.95 \mathrm{E}-26$ & $4.95 \mathrm{E}-26$ & 0.56 \\
\hline tree + species & 8 & -340.2 & 149.1 & $4.15 E-33$ & $4.15 E-33$ & 0.23 \\
\hline season + species & 8 & -398.3 & 91.1 & $1.68 \mathrm{E}-20$ & $1.68 \mathrm{E}-20$ & 0.58 \\
\hline species & 7 & -340.0 & 149.3 & $3.72 \mathrm{E}-33$ & $3.72 \mathrm{E}-33$ & 0.21 \\
\hline tree*season*species & 22 & -489.3 & 0.0 & $1.00 \mathrm{E}+00$ & $1.00 \mathrm{E}+00$ & 0.89 \\
\hline tree*season & 6 & -372.5 & 116.9 & $4.20 \mathrm{E}-26$ & 4.20E-26 & 0.57 \\
\hline tree ${ }^{*}$ species & 12 & -334.4 & 155.0 & $2.24 \mathrm{E}-34$ & $2.24 \mathrm{E}-34$ & 0.25 \\
\hline season*species & 12 & -472.3 & 17.0 & $2.01 \mathrm{E}-04$ & $2.02 \mathrm{E}-04$ & 0.82 \\
\hline tree & 4 & -326.4 & 163.0 & $4.12 \mathrm{E}-36$ & $4.12 \mathrm{E}-36$ & 0.02 \\
\hline season & 4 & -371.6 & 117.7 & $2.74 \mathrm{E}-26$ & $2.74 \mathrm{E}-26$ & 0.54 \\
\hline Intercept only & 3 & -326.5 & 162.8 & 4.49E-36 & 4.49E-36 & 0.25 \\
\hline \multicolumn{7}{|c|}{ Lignin (\%) } \\
\hline tree + season + species & 9 & -658.8 & 49.0 & $2.21 \mathrm{E}-11$ & $2.32 \mathrm{E}-11$ & 0.80 \\
\hline tree + season & 5 & -634.6 & 73.2 & $1.22 \mathrm{E}-16$ & $1.28 \mathrm{E}-16$ & 0.74 \\
\hline tree + species & 8 & -511.4 & 196.4 & $2.09 \mathrm{E}-43$ & $2.20 \mathrm{E}-43$ & 0.08 \\
\hline season + species & 8 & -658.6 & 49.2 & $1.94 \mathrm{E}-11$ & $2.04 \mathrm{E}-11$ & 0.80 \\
\hline species & 7 & -512.6 & 195.2 & $3.88 \mathrm{E}-43$ & $4.08 \mathrm{E}-43$ & 0.07 \\
\hline tree*season*species & 22 & -701.8 & 6.0 & 4.79E-02 & $5.03 \mathrm{E}-02$ & 0.89 \\
\hline tree*season & 6 & -633.5 & 74.3 & $6.94 \mathrm{E}-17$ & $7.29 \mathrm{E}-17$ & 0.75 \\
\hline tree ${ }^{*}$ species & 12 & -503.8 & 204.0 & $4.84 \mathrm{E}-45$ & $5.08 \mathrm{E}-45$ & 0.08 \\
\hline season*species & 12 & -707.8 & 0.0 & $9.52 \mathrm{E}-01$ & $1.00 \mathrm{E}+00$ & 0.88 \\
\hline tree & 4 & -513.6 & 194.3 & $6.26 \mathrm{E}-43$ & $6.58 \mathrm{E}-43$ & 0.01 \\
\hline season & 4 & -634.5 & 73.3 & $1.15 E-16$ & $1.21 \mathrm{E}-16$ & 0.74 \\
\hline Intercept only & 3 & -514.7 & 193.1 & $1.13 \mathrm{E}-42$ & $1.18 \mathrm{E}-42$ & 0.08 \\
\hline
\end{tabular}

The rows in bold indicate the best-fitting models with the lowest $\mathrm{AIC}$ value. $\mathrm{df}=$ degrees of freedom; $\mathrm{AIC}=\mathrm{Akaike}$ 's Information $\mathrm{Criterion} ; \triangle \mathrm{AIC}=\mathrm{difference} \mathrm{in}$ AIC between the given model and the model with the lowest AIC score; Weight = Akaike weight showing the relative support for each model; Likelihood = the likelihood of the model, an indicator of fit; Pseudo $\mathrm{R}^{2}=$ a generalized measure of the model coefficient of determination. 